\title{
Interest of the three dimensional analysis in brace treatment of idiopathic scoliosis. Prospective study
}

Jean-Claude Bernard

From 7th International Conference on Conservative Management of Spinal Deformities

Montreal, Canada. 20-22 May 2010

\section{Objectives}

Interest of a 3D reconstruction software to improve analysis of the three dimensional (3D) deformation of spine and results in the conservative treatment of idiopathic scoliosis.

\section{Material and methods}

Prospective comparative study in Centre des Massues (Lyon). Study of a group of 10 adolescents aged 10 to 15 for whom a 3D spine analysis was made before and after brace treatment, using Optispine software. The parameters of interest were correction of the Cobb angle, sagittal curves, and plane of maximal deformation (percentage of vertebrae in the plane, rotation, flexion, abduction).

\section{Results}

No significative difference was found between the two groups for the correction of frontal, sagittal plane, or for the plane of maximum deformation. Excluding the lumbar scoliosis (with a short brace correction), the results showed a significative difference in the correction of the thoracic kyphosis.

\section{Discussion}

The correction of the sagittal plane is an important parameter for the long term outcoming in children with idiopathic scoliosis. Therefore, it would be interesting to use this simple and fast 3D analysis to improve the quality of orthopaedic treatment.

CMCR des Massues, Lyon, France

Full list of author information is available at the end of the article

\section{Conclusion}

this preliminary study should be continued in a larger population to confirm these results and their implication in clinical practice.

Published: 10 September 2010

doi:10.1186/1748-7161-5-S1-072

Cite this article as: Bernard: Interest of the three dimensional analysis in brace treatment of idiopathic scoliosis. Prospective study. Scoliosis 2010 5(Suppl 1):072.
Submit your next manuscript to BioMed Central and take full advantage of:

- Convenient online submission

- Thorough peer review

- No space constraints or color figure charges

- Immediate publication on acceptance

- Inclusion in PubMed, CAS, Scopus and Google Scholar

- Research which is freely available for redistribution

Submit your manuscript at www.biomedcentral.com/submit
Ciomed Central 